\title{
審査の要点（審査員の立場から）
}

\author{
正 員 三木 一郎*

\section{The Point of Evaluation for Accreditation of Engineering Programs from Evaluator Viewpoint} \\ Ichiro Miki*, Member
}

\begin{abstract}
This report mainly describes the role of team chair and evaluator, the practical campus visit activities, and the evaluation content from the evaluator viewpoint.
\end{abstract}

キーワード : 審査長、審査員、審査員の役割、基準、審査内容

Keywords : team chair, program evaluator, role of evaluator, criteria, evaluation content

\section{1. はじめに}

2001 年度の試行審査に審査長として参加し、実地審査の 実際を経験した。試行であり、認定の合否の模擬判定結果 を高等教育機関（受審校）には通知しないが、認定基準に したがって公正な審査と判断を行った。2001年度は、電気 学会では 6 プログラムについて試行審査を行い、また、電 気・電子・情報通信分野ではないが、既に 3 プログラムが 認定されている。今後、本格的に本審査が開始されるよう になると、認定過程や認定結果について審査側、受審側双 方がこれまで以上に敏感になることが十分予想される。

審査を行うためには、審査員が必要になる。審査員とし て審査を実際に経験することは、自校が審査を受ける際に は学内指導者として中心的な役割を果たすことができ、自 プログラム認定に向けて貢献できると共に、我が国の技術 者教育にも寄与することとなる。審査員になるためには、 いくつかの条件があり、現状では審査員が不足すると考え られる。電気学会では、今後も審査員および学内指導者養 成のための研修会を随時開催する予定であり、積極的な参 加を要請したい。

本稿では、審査を行った経験をもとに、審査員の立場か ら主に実地審査の実際と審査における留意点などについて 述べることにする。

\section{2. 審査における役割および審査の開始}

審査を実施する場合、審査長と審査員あるいはオブザー バとでは果たさなければならない役割に違いがでてくる。 審査を行うこと自体は基本的に同じであるが、審査長は、 審査前の準備と審查後の報告書作成を行うことなどが求め

\footnotetext{
明治大学工学部

干214-8571 川崎市多摩区東三田 1-1-1

School of Science and Technology, Meiji University

1-1-1 Higashimita, Tama-ku, Kawasaki 214-8571
}

られるため、かなりの時間を費やさなければならない。そ こで、始めに実地審査以外の役割について審査長と審査員 に分けて、その概略を示すことにする。

〈2·1〉審査長の役割 審査長は、まず実地審査日程 について受審校および審査員と協議し決定する必要があ る。日程が決まると、以下に示す主な項目について、順次 進めることになる。

（1）審査スケジュールの立案、調整、連絡。

（2）自己点検書などが審查員に届いていることを確認 し、プログラム点検書の作成準備を促す。また、期日（実 地審査日の 2 週間前）までにそのプログラム点検書を審査 長に送付することを依頼する。

（3）追加資料等が必要か否か審查員にたずね、受審校に 送付あるいは準備を依頼する。

（4）審査員側が面談を希望する教職員、学生およびプロ グラム修了生を受審校に依頼し、審査員の面談担当などを 決定する。

（5）学生に対する合格の最低レベルが判定できる審査 方法について審査員と協議する。また、国際的に認知され る最低レベルについて審査員と協議する。

（6） ホテルや会議室、使用する機器などを受審校に依頼 する。

（7）受審校および審査員に日程やスケジュールなどに ついて最終確認を行う。

以上のことを精力的に進め、実地審査前日や当日の会議、 そして実地審査における進行役を務めなければならない。 実地審查後は、1 次および 2 次報告書を審査員の協力のも とで作成することが求められる。

〈2·2〉 審査員およびオブザーバの役割 審査員は自 己点検書や添付資料等に基づき審查を行い、プログラム点 検書を作成することが主な役割であるが、実地審査前から 報告書作成までの期間、審查長からの依頼や要請に協力す 
ることが必要である。

オブザーバは、試行審査では審査員と全く同じ役割を担 って審査に参加していただいているが、本審査では、審査 長から求められた場合に限り、意見を述べることができる。

次に、審査を行うに際し、審査員として何から手をつけ たらよいか考えてみたい。審査員は全員研修を受けている が、これを受講しただけでは実際の審査はできない。受審 校より自己点検書および添付資料等が送付されてきた時点 より審査が開始されるわけであるが、送付されてくるもの は一般に非常に厚い書類の束である。これを前にしてまず 多くの審査員は呆然とするにちがいない。審査の基本は、 何といっても認定基準の理解に始まる。これを繰り返し読 み、さらに実地審査の手引きや自己点検書作成の手引きを 読むとかなり全体像が明らかになってくる。その上で、自 己点検書および添付資料に取りかかるしかない。書類の審 査中にも認定基準や手引きを頻繁に参照し、基準や審査の 方法に間違いがないように十分な配慮をすることが肝要で ある。審査員は、認定基準や認定および審査方法などにつ いて疑問がある場合、審査長にたずねることになっており、 審査長はこれらのことを理解するために相当な時間を割か ねばならない。

以上より、審査長、審査員の役割等についてはある程度 ご理解いただけると思うが、審査長のロードはかなりハー ドであり、審査員の積極的な協力が不可欠である。

\section{3. 審査の実際}

前述のように、自己点検書等が手元に届いた時点から審 查は事実上開始されるわけであり、点検書の内容に関して 疑問や追加の資料等がある場合には、審査長を通して受審 校に請求することができる。あるいは予め受審校に準備を お願いすることができる。実地審査のやり方にはいくつか のパターンがあり、一概にどの方法がよいとはいえず、受 審校の場所、審査員の居所、交通の利便性などを考慮して 決めなければならない。ここでは、我々が実施した方法を 紹介する。

審査員はオブザーバを含めて 6 人であり、実地審査前日 の夕刻にホテルに集合し、午後 4 時から夕食 1 時間をはさ み 10 時 10 分まで、約 5 時間を費やして会議を行った。 ここで行った主な事柄は以下の通りである。

（1）各自のプログラム点検書を基に審查結果およびそ の根拠などを説明し、誤解して審査していないことなどに ついても確認する。

（2）質問の内容を整理し、大学側に提示を要請する資料 や面談に関する項目のリストを作成する。

（3）国際的に認知されるレベルと学生に対する合格の 最低レベル等について最終的な議論を行う。

（4）総括報告原案に関する意見を調整する。

翌日は、9 時にホテルを出発し、受審校で挨拶や打ち合 わせ等を済ませた後、10 時前から審査を開始した。前日 整理した質問事項などに沿って、審査長が質問を行い、さ
らに各審査員およびオブザーバが各自の懸案事項について 質問を行った。回答は、主に学科長、プログラム責任者が 行い、必要に応じて他の教授および事務局職員が回答した。 11 時 40 分から、約 1 時間で大学側が準備した各種書類 等について審査を行い、各自プログラム点検書に審査結果 を記入した。

昼食の後、基準について審査を続行し、午後 2 時 20 分 に書類および口頭による審査を終了し、施設見学に移った。 見学場所は、学科の実験室、コンピュータ室、教員の実験 室、LL 教室、講義室、図書館、学生情報室、売店、食堂、 体育館、トレーニングセンターなどである。4 時から、審 査員側が 3 グループに分かれ、教職員との面談を行い、 5 時半に 1 日目の審査を終了した。

夕食、休咊の後、午後 8 時 30 分より会議を開始し、委 員各自の審査結果とその根拠について説明した。その後、 プログラム点検書と総括報告文の原案を作成した。その他 の審議を行い、1 1 時終了。

2 日目は、同じく 9 時にホテルを出発し、9 時半より 1 時間学生との面談を行い、10 時 45 分から 2 時間かけて 審査員全員で最終審査結果について審議し、総括報告書を 作成した。昼食の後、実地審査最終面談を開始し、総括報 告書を朗読、プログラム点検書を受審校に手渡して実地審 查を終了した。なお、学科長に対し、プログラム点検書に 記載の事項や総括報告に対して事実関係等の誤認などがあ る場合には、2 週間以内にその修正を文書で要請できるこ とを口頭で伝達した。

\section{4. 審査における留意点と審査内容について}

〈4·1〉審査およびその準備 質問事項や追加資料等 があれば、予め受審校に通知し回答を得ておくと実地審査 をスムーズに進めることができる。また、審査員の分担な どを含め、綿密なスケジュールを立てておくことが制約時 間内に実地審査を終了させる条件の一つである。当然のこ とながら、審査基準について十分な検討・学習をしておく ことも条件である。

実地審査前日は、可能ならば早く集合し、その日に受審 校で審査を開始することが望ましいが、無理な場合には審 查員が疲れていないこの日にできるだけ多くの事項を審 議、調整、準備しておくことが必要である。実地審査は、 精神的にも体力的にもハードであり、十分体調を整えてお く必要があるが、実地審查中、午前、午後に各々 10 分程 度の休㮩をとるスケジュールをとるだけでも疲労は緩和さ れる。

審査チームは、少なくても 2 回は長時間の会議を行うが、 会議室を関係書類がそろっている受審校内に設定できれば 最も都合がよい。夜遅くまで会議が続くことになるので、 夕食のことを含め受審校とよく相談しておくことが望まし い。ホテルの会議室を使用すると高額となる。

学生との面談は、集団で実施した方が友好的な䨌囲気の 中で真実を聞くことができる。また、可能であれば、面談 
する学生の情報を予め得ておけば面談が実施しやすい。し かし、プライバシーの問題もあるので、学生の了解が必要 であろう。

その他、会議に必要なものとして、ノートパソコン（予 備を含め 2 台持参)、コピー機、延長コード、プロジェクタ、 スクリーン、プリンタ (持参) などが必要になるので、受 審校と調整をしておかねばならない。

〈4·2〉審査内容 ここでは、試行審査の結果より判 断し、審査員から見てプログラム側にとって満足すること が比較的難しいと思われる基準について挙げることにす る。

• 基準 $33.2 （ 1 ）$ カリキュラムの設計と学習・教育 目標への対応の公開

- 基準 33.3 （3）教員の教育貢献に対する評価方法 の公開と実施

• 基準 $6 \quad 6.2$ (1) 当該教育プログラムを改善してゆ くための具体的かつ継続的な方策の立案と実施

- 基準 5 (4) 学習・教育目標の総合的な達成度を判定 する評価基準を満たした学生のみを当該教育プログ ラムの修了生としていること

最後を除いて、プログラム側で創意工夫が必要となる項
目であり、例題もないため困難があったと思われる。しか し、現実にはこれらをほぼ満足するプログラムがあり、今 後それらを参考にしつつ、さらによい方法が生まれること が望ましい。

\section{5. まとめ}

審査員の立場から実地審査の実際と審査における留意点 などについて述べた。審査員になるには、始めに述べたよ うに年令等その他の条件があるが、決して難しいものでは ない。多くの方々のご参加を再度お願いしたい。本稿が、 今後の実地審査の参考になれば幸いである。

(平成 14 年 9 月 20 日受付)

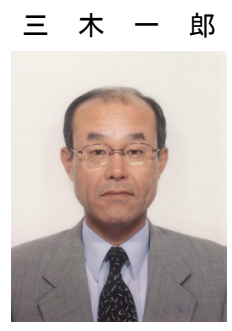

（正員） 1950 年 9 月 20 日生。 1978 年 3 月明 治大学大学院博士課程単位取得退学。同年同大 学工学部助手。専任講師、助教授を経て 1990 年 4 月同理工学部教授、現在に至る。主として、 モータ制御に関する研究に従事。1 1987 年 3 月 〜 1988 年 3 月米国ケンタッキー大学、カリフ オルニア大学デイビス校において客員研究員。 工学博士。IEEE 会員。 